\title{
ANALISIS RELEVANSI KURIKULUM KEJURUAN D3 TEKNIK MESIN DENGAN TUGAS AHLI MADYA DISAIN REKAYASA DI INDUSTRI PERMESINAN
}

\author{
Zainur Rofiq dan Yatin Ngadiyono \\ Pendidikan Teknik Mesin FT UNY \\ zainur_rofiq@yahoo.com
}

\begin{abstract}
Abstrak
Tujuan penelitian ini adalah menemukan besarnya relevansi kurikulum D3 Teknik Mesin FT UNY dengan tugas lulusan D3 Teknik Mesin yang bekerja sebagai Ahli Madya disain rekayasa di industri permesinan. Penelitian ini menggunakan pendekatan task analysis (analisis tugas) dengan analisis prosentase untuk mengukur tingkat relevansi kurikulum dan tugas Ahli Madya Disain Rekayasa di industri permesinan. Instrumen pengukuran tingkat kesulitan kurikulum dan tugas di industri mengacu pada buku "A Guide to Job Analysis" dengan mengambil skala General Education Development (GED). Skala GED terdiri dari Reasioning Development, Mathematical Development dan Language Development. Hasil perjodohan didapatkan 17,6\% materi kuliah Perencanaan Mesin kurang relevan, $17,6 \%$ relevan dan 74,7 \% sangat relevan dengan dengan tugas Ahli Madya Disain Rekayasa, namun demikian dari $74,7 \%$ yang sangat relevan hanya $33,6 \%$ yang mempunyai kontribusi sedangkan $41,1 \%$ hanya bersifat komplementer dan tidak memberikan kontribusi dalam implementasinya.
\end{abstract}

Kata kunci : relevansi, kurikulum D3, tugas ahli madya disain rekayasa

\begin{abstract}
The purpose of this study is to find the amount of curriculum relevance postgraduate Mechanical Engineering Study Program, Technical Faculty of Yogyakarta State University with the task of Mechanical Engineering postgraduate who worked as an Associate Expert in design engineering machinery industry. This research use task analysis with the percentage analysis to quantify the level of relevance between curriculum and engineering tasks in the machining industry. The Instruments measuring the level of difficulty curriculum and tasks in the industry refer to the book "A Guide to Job Analysis" by taking the General Education Development (GED) scale. GED scale consist of Reasioning Development, Mathematical Development and Language Development. The results obtained 17.6\% matchmaking Design Engineering course material is less relevant, $17.6 \%$ relevant and $74.7 \%$ very relevant to the task of Design Engineering Associate Expert, however, from $74.7 \%$ very relevant only $33.6 \%$ have contributed whereas only $41.1 \%$ is complementary and does not contribute to its implementation.
\end{abstract}

Keywords: relevance, curriculum postgraduate, tasks of design engineering associate expert 


\section{PENDAHULUAN}

Persoalan yang dihadapi perguruan tinggi di Indonesia secara umum tidak terlepas dari tiga isu pokok yaitu persoalan mutu, persoalan relevansi dan persoalan akses (Dikti,2004:8). Pola hubungan segitiga antara ilmu pengetahuan, industri dan universitas mendorong terciptanya jalinan komunikasi yang kuat dalam ketiganya dan menuntut langkah seiring sejalan, sehingga perkembangann ilmu pengetahuan, kebutuhan industri dengan sumber daya manusia yang dihasilkan oleh universitas semestinya mencirikan hubungan dengan konsep mutualisme.

Dari latar belakang yang telah diidentifikasi di atas peneliti ingin membatasi kurikulum yang terkandung dalam materi kuliah yang langsung terkait dengan tugas Ahli Madya Disain Rekayasa. Materi kuliah yang dimaksud adalah Perencanaan Mesin mahasiswa D3 FT UNY. Tugas Ahli Madya Disain Rekayasa dalam penelitian ini diambil dari tugas lulusan D3 Teknik Mesin yang telah mempunyai pengalaman kerja kurang dari dua tahun di PT Bukaka Teknik Utama Bogor. Pembatasan pengalaman kerja ini dimaksudkan untuk menjaga faktor-faktor di luar kompetensi yang di dapat oleh Ahli Madya Disain Rekayasa saat kuliah dulu..

Agar penelitian ini lebih terarah kepada masalah yang dituju, maka diajukan rumusan masalah penelitian sebagai berikut (1) Bagaimanakah materi kuliah Perencanaan Mesin pada kurikulum D3 Teknik Mesin FT UNY ? (2) Bagaimanakah tugas ahli madya disain rekayasa di industri permesinan ? (3) Seberapa besar relevansi materi kuliah Perencanaan Mesin D3 Teknik Mesin FT UNY dengan tugas ahli madya disain rekayasa di industri permesinan?

Perbaikan dan penyempurnaan kurikulum adalah bagian penting dalam pengembangan kurikulum seperti yang diungkapkan oleh Seller dan Miller (Sanjaya,2007:32) bahwa proses pengembangan kurikulum adalah rangkaian kegiatan yang dilakukan secara terus menerus yang dimulai dari menetukan orientasi kurikulum kemudian dikembangkan menjadi pedoman pembelajaran untuk kemudian dilaksanakan dalam proses belajar mengajar dan terakhir dilaksanakannya evaluasi.

Dakir (2004:85) mengatakan bahwa "pada era pambangunan seperti sekarang ini pengembangan kurikulum hendaknya memperhatikan link and match serta out put dengan lapangan kerja yang dibutuhkan". Artinya upaya melakukan pengembangan kurikulum tidak dapat melepaskan dari kebutuhan masyarakat.

Ditjen Dikti Depdiknas (2002:2) mengidentifikasikan pengembangan kurikulum di Perguruan Tinggi setidaknya diarahkan pada empat sasaran paradigmatis yaitu: pertama JPTK, UNDIKSHA, Vol. 13, No. 1, Januari 2016 : 85-97 
mengembangkan mutu dan relevansi penyelenggaraan program studi kedua pemberdayaan perguruan tinggi untuk mandiri bermasyarakat dalam penyelenggaraan program studi pilihannya secara santun dan bertanggungjawab ketiga mewujudkan akuntabilitas proses penyelenggaraan pendidikan tinggi yang terbuka oleh masyarakat keempat mengembangkan kebudayaan saling dapat dipercaya di kalangan masyarakat perguruan tinggi melalui proses evaluasi diri yang tersistem sebagai kebutuhan dalam menjaga eksistensinya.

Dacum merupakan metode yang sangat efektif untuk menganalisis sesuatu yang berhubungan dengan tugas dan jabatan dalam pekerjaan, dimana metode ini telah 40 tahun dipakai dalam mengembangkan analisis pekerjaan yang pada akhirnya digunakan untuk memperbaharui kurikulum program pendidikan dan pelatihan. Curtis \& Crunkilton (1979:115) menyatakan bahwa dacum merupakan metode yang paling banyak digunakan dalam mengembangkan kurikulum vokasional dimana langkahlangkahnya terdiri atas $(a)$ reviewing a written description of the specific occouption, $(b)$ identifying general areas a competences within the occouption, (c) identify specific skills or behaviors for each general area of competence, (d) structuring the skills into meaningfull learning sequances, (e) estabilishing level or competence for each skills as releated to realistic work situation.

\section{METODE PENELITIAN}

Penelitian ini menggunakan pendekatan task analysis (analisi tugas) dengan analisis prosentase untuk mengukur tingkat relevansi antara tingkat kesulitan pada kurikulum dan tugas disain rekayasa yang dilaksanakan di industri permesinan. Instrumen pengukuran tingkat kesulitan kurikulum dan tugas di industri mengacu pada buku "A Guide to Job Analysis" dengan mengambil skala General Education Development yang terdiri dari Reasioning Development, Mathematical Development dan Language Development

Penelitian ini dilakukan di Jurusan Pendidikan Teknik Mesin FT UNY dan PT Bukaka Teknik Utama Bogor. Populasi dalam penelitian ini adalah tugas-tugas yang dilakukan oleh jabatan setingkat setingkat Ahli Madya Disain Rekayasa di Industri Permesinan. Sampel penelitian diambil dengan teknik purposive sampling. Sampel yang dimaksud adalah sampel materi kuliah perencanaan mesin diambil dari silabus Prodi D3 Teknik Mesin FT UNY dan sampel materi tugas jabatan setingkat Ahli Madya Disain Rekayasa di industri permesinan didapatkan di PT. Bukaka Teknik Utama Bogor. 
Data penelitian yang terkumpul berupa tabel matrik hasil analisis tugas Ahli Madya Disain Rekayasa dan hasil analisis materi kuliah perencanaan teknik mesin, selanjutnya dilakukan analisis secara deskriptif. Perjodohan dilakukan untuk mengetahui presentase relevansi dengan prosedur sebagai berikut (1) membandingkan hasil analisis tugas di industri dengan materi kuliah perencanaan mesin (2) tanda sama dengan (=) diberikan pada hasil analisis materi kuliah yang sama dengan hasil analisis tugas, tanda sama dengan (+) diberikan pada hasil analisis materi kuliah lebih besar daripada hasil analisis tugas, tanda sama dengan (-) diberikan pada hasil analisis materi kuliah lebih kecil hasil analisis tugas.

Standar relevansi ditentukan dengan acuan relevansi standar normatif yaitu sangat relevan apabila hasil perjodohan bernilai lebih besar dari 66,6\%, cukup relevan apabila perjodohan bernilai antara 33,3\% - 66,5\%, dan kurang relevan apabila hasil perjodohan bernilai lebih kecil dari $33,2 \%$.

\section{HASIL PENELITIAN DAN PEMBAHASAN}

\section{Hasil Analisis Materi Kuliah Perencanaan Mesin}

Analisis Materi Kuliah Perencanaan Mesin berdasarkan tiga kelompok pengembangan yaitu kelompok pengembangan penalaran, matematis dan komunikasi. Tabel 1 di bawah ini menunjukkan tingkatan jenjang pokok-pokok bahasan pada materi kuliah Perencanaan Mesin. 
Tabel 1. Analisis Mata Kuliah Perencanaan Mesin

\begin{tabular}{|c|c|c|c|c|c|c|c|c|c|c|c|c|c|c|c|c|c|c|}
\hline \multirow{3}{*}{ No } & \multirow{3}{*}{ Kompetensi Dasar } & \multicolumn{17}{|c|}{ General Education Development } \\
\hline & & \multicolumn{6}{|c|}{ Pengembangan Penalaran } & \multicolumn{6}{|c|}{$\begin{array}{l}\text { Pengembangan } \\
\text { Matematis }\end{array}$} & \multicolumn{5}{|c|}{$\begin{array}{l}\text { Pengembangan } \\
\text { Komunikasi }\end{array}$} \\
\hline & & 1 & 2 & 3 & 4 & 5 & 6 & 1 & 2 & 3 & 4 & 5 & 6 & 1 & 2 & 3 & 4 & 5 \\
\hline 1 & Mencari ide perencanaan mesin & & & & $\mathrm{V}$ & & & & & & $\mathrm{v}$ & & & & & $\mathrm{V}$ & & \\
\hline 2 & Menentukan Pertimbangan & & & & & $\mathrm{V}$ & & & & & $\mathrm{v}$ & & & & & & $\mathrm{V}$ & \\
\hline 3 & Menentukan tuntutan perancangan & & & & & & $\mathrm{V}$ & & & & $\mathrm{v}$ & & & & & & & $\mathrm{V}$ \\
\hline 4 & Menentukan Ukuran Geometris & & & & & & $\mathrm{V}$ & & & & $\mathrm{V}$ & & & & & & & $\mathrm{V}$ \\
\hline 4 & Pembuatan Gambar Kerja & & & & & $\mathrm{V}$ & & & & & $\mathrm{v}$ & & & & & & & $\mathrm{V}$ \\
\hline 5 & Membuat Rancangan Biaya & & & & $\mathrm{V}$ & & & & & & $\mathrm{V}$ & & & & & & $\mathrm{V}$ & \\
\hline 6 & Membuat Rancangan Proses & & & & $\mathrm{V}$ & & & & & & $\mathrm{V}$ & & & & & & & $\mathrm{V}$ \\
\hline 7 & Membuat gambar rakitan (Assembling) & & & & $\mathrm{V}$ & & & & $\mathrm{V}$ & & & & & & & & $\mathrm{V}$ & \\
\hline 9 & Mempresentasikan hasil rancangan & & & & & & $\mathrm{V}$ & & & & $\mathrm{V}$ & & & & & & $\mathrm{V}$ & \\
\hline 10 & Mampu merevisi rancangan & & & & & & $\mathrm{V}$ & & & & $\mathrm{V}$ & & & & & & $\mathrm{V}$ & \\
\hline 11 & $\begin{array}{l}\text { Kemampuan menilai Kualitas Rancangan } \\
\text { Mesin }\end{array}$ & & & & & & $\mathrm{v}$ & & & & $\mathrm{v}$ & & & & & & $\mathrm{V}$ & \\
\hline & Jumlah & 0 & 0 & 0 & 4 & 2 & 5 & & 1 & & 10 & 0 & 0 & 0 & 0 & 1 & 6 & 4 \\
\hline & $\begin{array}{l}\text { Hasil Analisis Mata Kuliah Perencanaan Mesin } \\
(\%)\end{array}$ & 0 & 0 & 0 & 36,3 & 18,2 & 45,5 & & 9,1 & & 90,9 & 0 & 0 & 0 & 0 & 9,1 & 54,6 & 36,3 \\
\hline
\end{tabular}

Keterangan:

Hasil Analisis $=$ Jumlah item $\quad x 100 \%$

Jumlah sampel

Contoh: Analisis Mata Kuliah Perencanaan Mesin pada kelompok pengembangan panalaran jenjang 3

Hasil Analisis $=4 \quad \times 100 \%=36,3$

11

Analisis Relevansi Kurikulum Kejuruan.

.(Zainur Rofiq dan Yatin Ngadiyono) 
Analisis Mata Kuliah Perencanaan Mesin mahasiswa D3 Teknik Mesin FT UNY pada kelompok pengembangan penalaran 36,6\% materinya terletak pada jenjang 4 . Hal ini menunjukkan bahwa ada 36,6\% materi Kuliah Perencanaan Mesin yang menerapkan prinsip-prinsip rasional dalam menafsirkan standar-standar baku, bermacammacam perintah dan membuat urutan kerja. 18,2\% materinya terletak pada jenjang 5 . Hal ini menunjukkan bahwa $18,2 \%$ materi menerapkan pemikiran ilmiah dalam mendefinisikan masalah, pengumpulan data , mencari fakta dan menyajikan kesimpulankesimpulan. 45,5\% materi Kuliah Perencanaan Mesin terletak pada jenjang 6. Hal ini menunjukkan bahwa 45,5\% materi menerapan pemikiran ilmiah dalam menyelesaikan masalah-masalah yang berkaitan dengan rumus-rumus, persamaan-persamaan, grafikgrafik dan konsep-konsep keteknikan.

Pada kelompok pengembangan matematis $9,1 \%$ materinya terletak pada jenjang 2. Hal ini menunjukkan bahwa 9,1\% materi kuliah Perencanaan Mesin menggunakan perhitungan aritmatika untuk penjumlahan, pengurangan, perkalian atau pembagian bilangan bulat. 90,9\% materi Perkuliahan Perencanaan Mesin terletak pada jenjang 4 . Hal ini menunjukkan 90,9\% materi perkuliahan melakukan prosedur aritmatika, aljabar atau geometri dan penerapannya di bidang teknik.

Pada kelompok pengembangan komunikasi 9,1\% materi kuliah Perencanaan Mesin terletak pada jenjang 3. Hal ini menunjukkan bahwa 9,1\% materi perkuliahan pada tingkat menafsirkan perintah kerja, kode-kode atau simbol-simbol dan prosedur keteknikan. 54,6\% materi terletak pada jenjang 4 dapat diartikan bahwa 54,6\% materi kuliah Perencanaan Mesin memahami dan mengungkapkan data teknik, data disain, berdasarkan petunjuk atau tabel. 36,3\% materi terletak pada jenjang 5 menunjukkan bahwa materi kuliah Perencanaan Mesin pada tingkat membuat laporan, perencanaan atau mengevaluasi data perencanaan.

\section{Hasil Analisis Tugas Ahli Madya Disain Rekayasa}

Hasil analisis menunjukkan bahwa Tugas Ahli Madya Disain Rekayasa pada kelompok pengembangan penalaran $8,4 \%$ tugasnya terletak pada jenjang 3. Hal ini menunjukkan 8,4 \% Tugas Ahli Madya Disain Rekayasa di industri permesinan menerapkan pengertian umum melalui bentuk perintah secara tertulis, lisan atau diagram. 33,3\% tugas terletak pada jenjang 4, temuan ini menunjukkan bahwa 33,3\% Tugas Ahli Madya Disain Rekayasa di industri permesinan menerapkan prinsip-prinsip rasional dalam menafsirkan standar-standar baku, bermacam-macam perintah dan membuat urutan JPTK, UNDIKSHA, Vol. 13, No. 1, Januari 2016 : 85-97 
kerja. 25\% tugas terletak pada jenjang 5, hal ini menunjukkan bahwa Tugas tersebut $25 \%$ menerapkan pemikiran ilmiah dalam mendefinisikan masalah, pengumpulan data, mencari fakta dan menyajikan kesimpulan-kesimpulan. 45,5\% tugas terletak pada jenjang 6, hal ini menunjukkan bahwa 45,5\% materi menerapan pemikiran ilmiah dalam menyelesaikan masalah-masalah yang berkaitan dengan rumus-rumus, persamaanpersamaan, grafik-grafik dan konsep-konsep keteknikan

Pada kelompok pengembangan matematis $50 \%$ tugas terletak pada jenjang 3. Hal ini menunjukkan bahwa 50\% tugas Ahli Madya Disain Rekayasa di industri permesinan melakukan perhitungan matematis untuk bilangan pecahan, desimal, atau presentase. 50 $\%$ tugas terletak pada jenjang 4. Hal ini menunjukkan bahwa 50\% tugas melakukan prosedur aritmatika, aljabar atau geometri dan penerapannya di bidang teknik.

Pada kelompok pengembangan komunikasi 16,7 \% tugasnya terletak pada jenjang 3 , hal ini menunjukkan16,7\% tugas Ahli Madya Disain Rekayasa pada tingkat menafsirkan perintah kerja, kode-kode atau simbol-simbol dan prosedur keteknikan. 33,3\% tugas terletak pada jenjang 4, hal ini menunjukkan 33,3\% tugas Ahli Madya Disain Rekayasa memahami dan mengungkapkan data teknik, data disain, berdasarkan petunjuk atau tabel. $50 \%$ tugas terletak pada jenjang 5, hal ini menunjukkan 50\% tugas Ali Madya Disain Rekayasa pada tingkat membuat laporan, perencanaan atau mengevaluasi data perencanaan. 
Tabel 2 Analisis Tugas Ahli Madya Disain Rekayasa

\begin{tabular}{|c|c|c|c|c|c|c|c|c|c|c|c|c|c|c|c|c|c|c|}
\hline \multirow{3}{*}{ No } & \multirow{3}{*}{ Kompetensi Dasar } & \multicolumn{17}{|c|}{ General Education Development } \\
\hline & & \multicolumn{6}{|c|}{ Pengemb. Penalaran } & \multicolumn{6}{|c|}{ Pengemb. Matematis } & \multicolumn{5}{|c|}{ Pengemb. Komunikasi } \\
\hline & & 1 & 2 & 3 & 4 & 5 & 6 & 1 & 2 & 3 & 4 & 5 & 6 & 1 & 2 & 3 & 4 & 5 \\
\hline 1 & Menggambarkan sketsa komponen benda kerja. & & & & $\mathrm{V}$ & & & & & & $\mathrm{V}$ & & & & & $\mathrm{V}$ & & \\
\hline 2 & Membaca gambar teknik & & & & $\mathrm{V}$ & & & & & & $\mathrm{V}$ & & & & & & $\mathrm{V}$ & \\
\hline 3 & Memilih gambar teknik yang benar & & & & $\mathrm{V}$ & & & & & & $\mathrm{V}$ & & & & & & $\mathrm{V}$ & \\
\hline 4 & Mengidentifikasi tuntutan gambar & & & & $\mathrm{V}$ & & & & & & $\mathrm{V}$ & & & & & & $\mathrm{V}$ & \\
\hline 5 & Membuat perubahan pada gambar permesinan & & & & & $\mathrm{V}$ & & & & & $\mathrm{V}$ & & & & & & & $\mathrm{V}$ \\
\hline 6 & Mempersiapkan daftar bagian-bagian engineering & & & $\mathrm{V}$ & & & & & & $\mathrm{V}$ & & & & & & $\mathrm{V}$ & & \\
\hline 7 & Menentukan persyaratan komponen dan/atau material & & & & & & $\mathrm{V}$ & & & & $\mathrm{V}$ & & & & & & & $\mathrm{v}$ \\
\hline 8 & $\begin{array}{l}\text { Mempersiapkan perakitan, tata letak dan rancangan } \\
\text { gambar secara rinci }\end{array}$ & & & & & $\mathrm{V}$ & & & & $\mathrm{V}$ & & & & & & & & $\mathrm{v}$ \\
\hline 9 & $\begin{array}{l}\text { Menterjemahkan spesifikasi-spesifikasi dan pemilihan } \\
\text { material, komponen dan/atau perakitan }\end{array}$ & & & & & $\mathrm{V}$ & & & & $\mathrm{v}$ & & & & & & & & $\mathrm{v}$ \\
\hline 10 & Memeriksa gambar & & & & & & $\mathrm{V}$ & & & $\mathrm{V}$ & & & & & & & $\mathrm{V}$ & \\
\hline 11 & Menggambar 2 dimensi dengan sistem CAD & & & & & & $\mathrm{V}$ & & & $\mathrm{V}$ & & & & & & & & $\mathrm{v}$ \\
\hline \multirow[t]{3}{*}{12} & Membuat dan memodifikasi model 3D & & & & & & $\mathrm{V}$ & & & $\mathrm{V}$ & & & & & & & & $\mathrm{V}$ \\
\hline & Jumlah & 0 & 0 & 1 & 4 & 3 & 4 & 0 & 0 & 6 & 6 & 0 & 0 & 0 & 0 & 2 & 4 & 6 \\
\hline & Hasil Analisis Tugas Ahli Madya Disain Rekayasa (\%) & 0 & 0 & 8,4 & 33,3 & 25 & 33,3 & 0 & 0 & 50 & 50 & 0 & 0 & 0 & 0 & 16.7 & 33,3 & 50 \\
\hline
\end{tabular}

JPTK, UNDIKSHA, Vol. 13, No. 1, Januari 2016 : 85-97 
Tabel 2 di atas menunjukkan bahwa Tugas Ahli Madya Disain Rekayasa pada kelompok pengembangan penalaran 8,4\% tugasnya terletak pada jenjang 3, 33,3\% tugas terletak pada jenjang $4,25 \%$ tugas terletak pada jenjang 5 dan , 33,3\% tugas terletak pada jenjang 6.

Pada kelompok pengembangan matematis $50 \%$ tugas terletak pada jenjang 3 dan $50 \%$ terletak pada jenjang 4. Pada kelompok pengembangan komunikasi 16,7\% tugasnya terletak pada jenjang 3, 33,3\% tugas terletak pada jenjang 4 dan $50 \%$ tugas terletak pada jenjang 5 .

\section{Hasil Analisis Perjodohan Materi Kuliah Perencanaan Mesin dengan Tugas Ahli Madya Disain Rekayasa}

Hasil perjodohan dengan tanda (=) ditemukan kesamaan pada hasil analisis tugas dan hasil analisis materi kuliah Perencanaan Mesin dengan angka perolehan masing-masing 0 $\%$ sebanyak 7 pasangan. Kasus ini ditemuan kesamaan pada hasil analisis tugas dan hasil analisis materi kuliah Perencanaan Mesin yaitu 0\% sehingga kasus ini tidak memberikan kontribusi positif pada implementasinya. Hasil perjodohan dengan tanda (+) ditemukan pada hasil analisis materi kuliah Perencanaan Mesin dan hasil analisis tugas sebanyak 5 pasangan, Temuan ini memberikan arti bahwa terdapat 5,8\% materi kuliah Perencana Mesin yang kurang relevan dengan tugas Ahli Madya Disain Rekayasa, walaupun sajian Materi kuliah mempunyai kapasitas sajian yang lebih besar, tidak berarti kedalaman dan keluasan materi yang disajikan memiliki kesesuaian seperti yang dibutuhkan industri.

Hasil perjodohan dengan tanda (-) ditemukan pada hasil analisis materi kuliah Perencanaan Mesin dan hasil analisis tugas diketahui bahwa 11,8\% berstandar sangat relevan. Temuan ini berarti walaupun terdapat kapasitas sajian materi kuliah Perencanaan Mesin yang lebih kecil dari yang dibutuhkan industri, namun terdapat 11,8\% materi tersebut yang mempunyai kesenjangan yang kecil pada tingkat kedalaman dan keluasan materinya. 
Tabel 3 Hasil Analisis Perjodohan Materi Kuliah Perencanaan Mesin dengan Tugas Ahli Madya Disain Rekayasa

\begin{tabular}{|c|c|c|c|c|c|c|c|c|c|c|c|c|c|c|c|c|c|}
\hline \multirow[t]{3}{*}{ Kompetensi Dasar } & \multicolumn{17}{|c|}{ General Education Development } \\
\hline & \multicolumn{6}{|c|}{ Pengembangan Penalaran } & \multicolumn{6}{|c|}{ Pengembangan Matematis } & \multicolumn{5}{|c|}{ Pengembangan Komunikasi } \\
\hline & 1 & 2 & 3 & 4 & 5 & 6 & 1 & 2 & 3 & 4 & 5 & 6 & 1 & 2 & 3 & 4 & 5 \\
\hline $\begin{array}{l}\text { Hasil Analisis Mata Kuliah } \\
\text { Perencanaan Mesin }(\%)\end{array}$ & 0 & 0 & 0 & 36,3 & 18,2 & 45,5 & 0 & 9,1 & 0 & 90,9 & 0 & 0 & 0 & 0 & 9,1 & 54,6 & 36,3 \\
\hline $\begin{array}{l}\text { Hasil Analisis Tugas Ahli Madya } \\
\text { Disain Rekayasa (\%) }\end{array}$ & 0 & 0 & 8,4 & 33,3 & 25 & 33,3 & 0 & 0 & 50 & 50 & 0 & 0 & 0 & 0 & 16.7 & 33,3 & 50 \\
\hline $\begin{array}{l}\text { Pasangan Tugas AMDR dengan Mata } \\
\text { Kuliah Perencanaan Mesin }\end{array}$ & 100 & 100 & 0 & 91,7 & 72,8 & 73,1 & 100 & 0 & 0 & 55 & 100 & 100 & 100 & 100 & 64.5 & 61 & 72,6 \\
\hline Jenis Tanda & $=$ & $=$ & - & + & - & + & $=$ & + & - & + & $=$ & $=$ & $=$ & $=$ & - & + & - \\
\hline
\end{tabular}

Keterangan:

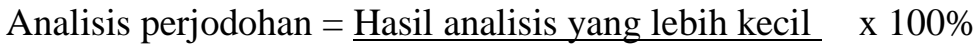

Hasil analisis yang lebih besar

Contoh: Analisis perjodohan Mata Kuliah Perencanaan Mesin dan Tugas Ahli Madya Disain Rekayasa pada kelompok pengembangan panalaran jenjang 4

Hasil Perjodohan $=\underline{33,3} \quad \times 100 \%=91,7 \%$

$$
36,3
$$

JPTK, UNDIKSHA, Vol. 13, No. 1, Januari 2016 : 85-97 
Pada Tabel 3 di atas terlihat bahwa hasil perjodohan dengan tanda (=) ditemukan kesamaan pada hasil analisis tugas dan hasil analisis materi kuliah Perencanaan Mesin sebanyak $41,1 \%$. Hasil perjodohan dengan tanda (+) ditemukan pada hasil analisis materi kuliah Perencanaan Mesin dan hasil analisis tugas sebanyak29,4\%, hasil perjodohan dengan tanda (-) ditemukan pada hasil analisis materi kuliah Perencanaan Mesin dan hasil analisis tugas sebanyak $29,4 \%$.

Tabel 4 Rangkuman Standar Normatif Relevansi Hasil Pasangan Berdasarkan Tanda Pembahasan dan Persentase

\begin{tabular}{|l|l|l|l|l|}
\hline Jenis Tanda & \multicolumn{4}{|l|}{ Relevansi Standar Normatif dalam (\%) } \\
\hline & K. Relevan & C .Relevan & S. Relevan & Jumlah \\
\hline Tanda (=) & & & 41,1 & 41,1 \\
\hline Tanda (+) & 5,8 & 11,8 & 11,8 & 29,4 \\
\hline Tanda ( - ) & 11,8 & 5,8 & 11,8 & 29,4 \\
\hline Total & & 100 \\
\hline
\end{tabular}

\section{SIMPULAN}

Pada kelompok pengembangan penalaran, $36 \%$ materi Kuliah Perencanaan Mesin menerapkan prinsip-prinsip rasional dalam menafsirkan standar-standar baku, bermacam-macam perintah dan membuat urutan kerja. 18,2\% menerapkan pemikiran ilmiah dalam mendefinisikan masalah, pengumpulan data, mencari fakta dan menyajikan kesimpulan-kesimpulan. dan $45,5 \%$ menerapan pemikiran ilmiah dalam menyelesaikan masalah-masalah yang berkaitan dengan rumus-rumus, persamaan-persamaan, grafikgrafik dan konsep-konsep keteknikan.

Pada kelompok pengembangan matematis 9,1\% kuliah Perencanaan Mesin menggunakan perhitungan aritmatika untuk penjumlahan, pengurangan, perkalian atau pembagian bilangan bulat. 90,9\% materi perkuliahan melakukan prosedur aritmatika, aljabar atau geometri dan penerapannya di bidang teknik.

Pada kelompok pengembangan komunikasi 9,1\% materi kuliah Perencanaan Mesin menafsirkan perintah kerja, kode-kode atau simbol-simbol dan prosedur keteknikan. 54,6\% materi kuliah Perencanaan Mesin memahami dan mengungkapkan data teknik, data disain, berdasarkan petunjuk atau tabel dan 36,3\% materi membuat laporan, perencanaan atau mengevaluasi data perencanaan.

Tugas Ahli Madya Disain Rekayasa pada kelompok pengembangan penalaran $8,4 \%$ menerapkan pengertian umum melalui bentuk perintah secara tertulis, lisan atau 
diagram. 33,3\% tugas menerapkan prinsip-prinsip rasional dalam menafsirkan standarstandar baku, bermacam-macam perintah dan membuat urutan kerja. 25\% tugas menerapkan pemikiran ilmiah dalam mendefinisikan masalah, pengumpulan data, mencari fakta dan menyajikan kesimpulan-kesimpulan. 45,5\% menerapan pemikiran ilmiah dalam menyelesaikan masalah-masalah yang berkaitan dengan rumus-rumus, persamaan-persamaan, grafik-grafik dan konsep-konsep keteknikan

Pada kelompok pengembangan matematis $50 \%$ tugas terletak pada jenjang 3 . Hal ini menunjukkan bahwa 50\% tugas Ahli Madya Disain Rekayasa di industri permesinan melakukan perhitungan matematis untuk bilangan pecahan, desimal, atau presentase. 50 $\%$ tugas terletak pada jenjang 4 . Hal ini menunjukkan bahwa 50\% tugas melakukan prosedur aritmatika, aljabar atau geometri dan penerapannya di bidang teknik.

Pada kelompok pengembangan komunikasi 16,7 \% tugasnya terletak pada jenjang 3, hal ini menunjukkan16,7\% tugas Ahli Madya Disain Rekayasa pada tingkat menafsirkan perintah kerja, kode-kode atau simbol-simbol dan prosedur keteknikan. 33,3\% tugas terletak pada jenjang 4, hal ini menunjukkan 33,3\% tugas Ahli Madya Disain Rekayasa memahami dan mengungkapkan data teknik, data disain, berdasarkan petunjuk atau tabel. $50 \%$ tugas terletak pada jenjang 5, hal ini menunjukkan 50\% tugas Ali Madya Disain Rekayasa pada tingkat membuat laporan, perencanaan atau mengevaluasi data perencanaan.

Hasil perjodohan didapatkan $41,1 \%$ terdapat kesamaan pada hasil analisis tugas dan hasil analisis materi kuliah Perencanaan Mesin namun kesamaan tersebut karena sama-sama tidak terdapat materi sehingga tidak memberikan kontribusi positif pada implementasinya. Ada 5,8 \% materi kuliah Perencana Mesin yang kurang relevan dengan tugas Ahli Madya Disain Rekayasa. Ada 11,8\% materi kuliah Perencanaan Mesin dan tugas Ahli Madya Disain Rekayasa berstandar sangat relevan.

\section{DAFTAR PUSTAKA}

Alhumami, Amich. (2008). Pendidikan Tinggi dan Globalisasi. [Ofline] Tersedia: els.bappenas.go.id/upload/kliping/Pendidikan\%20tinggi.pdf [30 Agustus 2008].

Division of Occupational Analysis.(2008).A Guide to Job Analysis. Wisconsin: US Departement of Labor.

Irawan, Doni . (2008). Pelaksanaan Sistem Ekonomi Pancasila di Tengah Praktek Liberalisasi Ekonomi di Indonesia [Ofline] Tersedia:

JPTK, UNDIKSHA, Vol. 13, No. 1, Januari 2016 : 85-97 
images.zanikhan.multiply.com/attachment/O/SBdKgoKCtcAAFtBbY81/Ekon omi.doc?nmid=94632695 - [23 Oktober 2008].

Mudjiran, Paulus (2008). BHP, McDonaldisasi Pendidikan. [Ofline] Tersedia: http://www.sinarharapan.co.id/berita/0802/28/opi01.html [19 september 2008].

Mulyawan, Iwan.Merealisasikan KBK melalui Pembelajaran [Ofline] Tersedia: http://www.kursuskomputerku.com/data/Presentasi/BCEP\%20Presentation.pdf [1 Oktober 2009].

Robert E. Norton. (2005). Dacum Handbook. Ohio.The National Center for Research in Vocational Education The Ohio State University.

Rizal, Syamsu.Kurikulum Berbasis Kompetensi. [Ofline] Tersedia: http://ajrcaceh.org/wp-content/uploads/2009/01/makalah-samsul-rizal.pdf [1 Oktober 2009].

Suparman, Atwi. (2001). "Desain Instruksional” Jakarta. Pusat Antar Universitas untuk Peningkatan Pengembangan Aktivitas Instruksional Dirjen Dikti Depdiknas.

Taba, Hilda.(1962).Curriculum Development,Theory and Practice. New York. Harcourt, Brace \& World.

Tyler, R.W.(1949). Basic Principles of Curriculum and Instructions. Univ. Of Chicago Press.

Undang-Undang Nomor 20 Tahun 2003 Tentang : Sistem Pendidikan Nasional. Jakarta.

Undang-undang Nomor 09 tahun 2009 Tentang: Badan Hukum Pendidikan. Jakarta

World Health Organization (2000). Need Assesment. Workbook3. WHO/MSD/MSB $00.2 \mathrm{~d}$.

Zais, Robert S. (1976).Curriculum Principles and Foundation. London. Harper and Row. 